\title{
Activating ERBB3 Mutation
}

National Cancer Institute

\section{Source}

National Cancer Institute. Activating ERBB3 Mutation. NCI Thesaurus. Code C141370.

A change in the nucleotide sequence of the ERBB3 gene that that results in constitutive activation of receptor tyrosine-protein kinase erbB-3 and its downstream signaling pathways. 